Jurnal Pendidikan Ekonomi \& Bisnis, 6 (1) 2018, 1-14
JURNAL PENDIDIKAN EKONOMI \& BISNIS
http://journal.unj/unj/index.php/jpeb

\title{
Pengaruh Modal, Lama Usaha dan Lokasi Terhadap Pendapatan Pedagang Pasar Pasca Relokasi
}

\author{
Khasan Setiaji ${ }^{1}$, Ana Listia Fatuniah2 ${ }^{*}$ \\ ${ }^{1}$ Fakultas Ekonomi, Universitas Negeri Semarang, Indonesia \\ ${ }_{2}^{2}$ Fakultas Ekonomi, Universitas Negeri Semarang, Indonesia
}

\section{Article Info}

Article history:

Received: 18 January 2018;

Accepted: 1 February 2018;

Published: 1 March 2018.

Keywords:

Income, capital; length of trading; location

\begin{abstract}
This study aims to find out the effect of capital, length of trading, and location toward the traders income Johar market in Semarang City both simultenously and partially. The sample is 92 traders. The result of the study showed that the significant value of $0,000<0,05$ and the value of $F_{\text {count }}(74,922)$ is higher than $F_{\text {table }}(2,71)$ and Adjust $R$ Square of 0,709 (70,9\%). Capital gives positive effect on traders income in Johar market Semarang obtains the significant value of $0,000<0,05$ and the value of $t_{\text {count }}(5,853)$ higher than $t_{\text {table }}(1,987)$ and $r$-squareof $27,9 \%$. The length of trading gives positive effect on traders income in Johar market Semarang obtains the significant value of $0,000<0,05$ and the value of $t_{\text {count }}$ $(3,635)$ higher than table $(1,987)$ and $r$-squareof $13,0 \%$. Location gives positive effect on the traders income in Johar market Semarang obtains the significant value of $0,000<0,05$ and the value of $t_{\text {count }}(4,658)$ higher than $t_{\text {table }}(1,987)$ and $r$-square of $19,8 \%$. The conclusion is that there is a positive effect of capital, length, and location of trading toward the traders income Johar market in Semarang City.
\end{abstract}

\begin{abstract}
Abstrak
Penelitian ini bertujuan untuk mengetahui pengaruh modal, lama usaha, dan lokasi terhadap pendapatan pedagang pasca relokasi Pasar Johar di Kota Semarang secara simultan maupun secara parsial. Sampel dalam penelitian berjumlah 92 pedagang. Hasil penelitian menunjukkan bahwa nilai signifikansi sebesar $0,000<0,05$ dan nilai $F_{\text {hitung }}$ $(74,922)$ yaitu lebih besar dari $\mathrm{F}_{\text {tabel }}(2,71)$ dan Adjust $\mathrm{R}$ Square sebesar 0,709 (70,9\%). Modal berpengaruh positif terhadap pendapatan pedagang di Pasar Johar Semarang diperoleh nilai signifikansi sebesar $0,000<0,05$ dan nilai thitung $(5,853)$ lebih besar dari tabel $(1,987)$ dan $r-$ square sebesar $27,9 \%$. Lama usaha berpengaruh positif terhadap pendapatan pedagang di Pasar Johar Semarang diperoleh nilai signifikansi sebesar $0,000<0,05$ dan nilai thitung $(3,635)$ lebih besar dari tabel $(1,987)$ dan $r$-square sebesar $13,0 \%$. Lokasi berpengaruh positif terhadap pendapatan pedagang di Pasar Johar Semarang diperoleh nilai signifikansi sebesar $0,000<0,05$ dan nilai thitung $(4,658)$ lebih besar dari tabel $(1,987)$ dan $r$-square sebesar $19,8 \%$. Simpulan dari penelitian ini adalah terdapat pengaruh positif dan signifikan modal, lama usaha dan lokasi terhadap pendapatan pedagang pasca relokasi Pasar Johar di Kota Semarang.
\end{abstract}

How to Cite:

Setiaji, K.,\& Fatuniah, L.F. (2018). Pengaruh Modal, Lama Usaha dan Lokasi Terhadap Pendapatan Pedagang Pasar Pasca Relokasi. Jurnal Pendidikan Ekonomi \& Bisnis, 6 (1) 2018, 1-14.

* Corresponding Author. 


\section{PENDAHULUAN}

Masalah pokok bidang kependudukan di Indonesia adalah perkembangan penduduk yang relatif tinggi, adanya struktur umur yang tidak seimbang, distribusi pendapatan yang tidak merata dan kualitas tenaga kerja yang rendah (Irawan \& Suparmoko,1992:45). Pembangunan ekonomi merupakan suatu proses yang menyebabkan pendapatan perkapita penduduk suatu masyarakat meningkat dalam jangka panjang (Sukirno, 2000). Pembangunan ekonomi memiliki tujuan distribusi pendapatan dan peningkatan kesejahteraan masyarakat yaitu dengan penyediaan lapangan kerja yang luas sehingga dapat menyerap tenaga kerja, mengurangi tingkat pengangguran dan meningkatkan pendapatan sehingga juga dapat meningkatkan taraf hidup atau kesejahteraan masyarakat yang ada di suatu negara atau daerah.

Lapangan pekerjaan pada sektor formal menjadi prioritas bagi tenaga kerja, namun akibat adanya krisis ekonomi yang melanda Indonesia pada tahun 1998 yang akhirnya berdampak besar pada perekonomian Indonesia yaitu banyak perusahaanperusahan besar yang bergerak disektor formal menutup usahanya karena tidak mampu bertahan, sehingga membawa dampak buruk seperti Pemutusan Hubungan Kerja (PHK). Dewasa ini, peluang masuk pada sektor formal semakin sempit dan sedikit, mengingat bahwa sektor formal menuntut seseorang untuk memiliki keterampilan dan pendidikan tinggi yang diperoleh melalui pendidikan formal sehingga bagi seseorang yang tidak dapat memenuhi syarat tersebut akan berpeluang kecil untuk bekerja pada sektor formal sehingga mereka memilih alternatif lain yaitu bekerja pada sektor informal. Sektor informal berperan cukup penting dalam menopang perekonomian. Setidaknya ketika lapangan pekerjaan kurang memadai pada sektor formal, sektor informal mampu menjadi penopang bagi tenaga kerja yang tidak dapat tertampung ke dalam sektor formal, sehingga hal tersebut dapat mengurangi tingkat pengangguran di suatu negara atau daerah.

Terlebih adanya tantangan dalam era keterbukaan perdagangan (openness to trade). Meskipun keterbukaan perdagangan ASEAN mampu mendorong perekonomian dengan pergerakan yang selaras. Namun diperlukan peningkatan daya saing khususnya sektor informal (Dinan, A., Kuncoro W., H., \& Iranto, D. (2017).

Sektor informal merupakan unit usaha kecil dengan modal kecil serta sistem pengelolaannya sangat sederhana. Sektor informal cukup dominan menyerap angkatan kerja khususnya di perkotaan. Salah satu kegiatan usaha di sektor informal yaitu perdagangan. Kegiatan berdagang lebih banyak digeluti oleh sebagian besar masyarakat karena tanpa keahlian khusus atau pendidikan yang tinggi bisa masuk dengan mudah ke dalam kegiatan sektor informal tersebut salah satunya menjadi seorang pedagang (tabel 1).

Kota Semarang merupakan ibu kota Provinsi Jawa Tengah sekaligus kota metropolitan terbesar kelima di Indonesia. Berdasarkan tabel 1 sektor perdagangan menduduki urutan ketiga dan tiap tahun mengalami peningkatan yaitu pada tahun 2013 sebanyak 86.175 jiwa, tahun 2014 sebanyak 86.256 jiwa dan mengalami peningkatan kembali pada tahun 2015 sebanyak 86.820 jiwa. Sektor informal perdagangan dapat dijadikan sebagai penopang bagi tenaga kerja yang tidak dapat tertampung atau terserap ke dalam sektor formal dan mengurangi tingkat pengangguran di Kota Semarang.

Tabel 1. Jumlah Penduduk Menurut Mata Pencaharian di Kota Semarang

\begin{tabular}{ccccc}
\hline No & Mata Pencaharian & 2013 & 2014 & 2015 \\
\hline 1 & Buruh industri & 176.635 & 176.801 & 177956 \\
2 & PNS dan TNI/Polri & 94.748 & 94.837 & 95457 \\
3 & Pedagang & 86.175 & 86.256 & 86820 \\
4 & Buruh bangunan & 82.766 & 82.844 & 83385 \\
5 & Jasa Lainnya & 81.702 & 81.779 & 82313 \\
\hline
\end{tabular}

Sumber : BPS Kota Semarang, 2015 
Selain itu kontribusi sektor perdagangan terhadap Produk Domestik Regional Bruto (PDRB) di Kota Semarang secara berturut-turut berada di peringkat tertinggi ketiga setelah sektor industri pengolahan dan konstruksi serta sektor lainnya. Distribusi PDRB sektor perdagangan pada tahun 2013 sebesar 14,93\%, tahun 2014 sebesar $14,39 \%$, tahun 2015 sebesar $14,12 \%$ dan tahun 2016 sebesar 14,06\%. Hal tersebut menunjukkan bahwa sektor perdagangan merupakan salah satu sektor yang penting dalam perekonomian di Provinsi Jawa Tengah dan Kota Semarang.

Dalam kegiatan perdagangan, pasar memiliki peranan yang sangat penting bagi semua pelaku ekonomi. Terutama, dalam memenuhi kebutuhan dan keinginannya tersebut. Salah satu kegiatan perdagangan yaitu pada pasar tradisional. Dalam Peraturan Daerah Kota Semarang Nomor 9 Tahun 2013 tentang pengaturan pasar tradisional bahwa pasar mempunyai peran strategis dalam kehidupan ekonomi dan sosial masyarakat. Hal ini karena pasar menjadi tempat yang mampu menggerakkan roda perekonomian demi pemenuhan kebutuhan masyarakat melalui kegiatan jual beli. Tabel 2 merupakan data jumlah pasar berdasarkan jenis pasar di Kota Semarang tahun 2011-2015.

Jumlah pasar modern lebih banyak dibandingkan dengan pasar umum atau yang disebut pasar tradisional di Kota Semarang. Pesatnya perkembangan pasar modern tersebut dikhawatirkan dapat mematikan eksistensi pasar tradisional yang ada di Kota Semarang. Kegiatan perdagangan di pasar tidak lepas dari kendala, salah satunya yaitu relokasi atau pemindahan lokasi pasar yang baru serta revitalisasi pasar yang dilakukan oleh pemerintah. Pasar Johar merupakan salah satu pasar tradisional di Kota Semarang yang di relokasi oleh Pemerintah Kota Semarang. Relokasi Pasar Johar dilakukan karena kondisi fisik yang sudah tidak layak ditempati karena terkena musibah kebakaran, sehingga Pemerintah Daerah Kota Semarang melakukan kegiatan relokasi pedagangnya ke kawasan Masjid Agung Jawa Tengah (MAJT) yaitu berada di Jalan Arteri Soekarno-Hatta di Kelurahan Sambirejo Kecamatan Gayamsari Semarang.

Jumlah pedagang Pasar Johar Semarang antara sebelum dan sesudah relokasi mengalami penurunan yang cukup drastis yaitu sebelum relokasi jumlah pedagang sebanyak 6.087 pedagang yang terdiri dari gabungan pedagang dari delapan pasar yaitu Pasar Johar Utara, Pasar Johar Tengah, Pasar Johar Selatan, shoping center Johar, Pasar Yaik Permai, Pasar Yaik Baru, Pasar Pungkuran dan Pasar Kanjengan. Namun, setelah dilakukan relokasi terjadi penurunan pedagang di mana saat ini hanya terdiri dari pedagang dari Pasar Johar Utara, Pasar Johar Tengah dan Pasar Johar Selatan sebanyak 1.206 pedagang. Menurut Kepala Dinas UPTD Pasar Johar Semarang, pedagang telah mengalami kerugian karena musibah kebakaran tersebut dan pedagang memilih tidak melanjutkan usaha berdagang atau gulung tikar dikarenakan keterbatasan modal untuk menjalankan usaha berdagangnya.

Adanya kegiatan relokasi pasar tersebut dapat mempengaruhi aktifitas

Tabel 2. Jumlah Pasar Berdasarkan Jenis Pasar di Kota Semarang

\begin{tabular}{lccccc}
\hline Jenis Pasar & 2011 & 2012 & 2013 & 2014 & 2015 \\
\hline Departemen Store & 10 & 10 & 10 & 10 & 10 \\
Pasar Swalayan & 52 & 52 & 53 & 53 & 53 \\
Pusat Perbelanjaan & 2 & 2 & 2 & 2 & 2 \\
Pasar Umum & 47 & 47 & 47 & 47 & 47 \\
Pasar Hewan & 1 & 1 & 1 & 1 & 1 \\
Pasar Buah & 1 & 1 & 1 & 1 & 1 \\
Pasar Sepeda & 1 & 1 & 1 & 1 & 1 \\
Pasar Ikan & 2 & 2 & 2 & 2 & 2 \\
Lain-lain & 3 & 3 & 3 & 3 & 3 \\
Total & 119 & 119 & 120 & 120 & 120 \\
\hline
\end{tabular}

Sumber : BPS Kota Semarang, 2016 
berdagang yang tidak sama seperti biasanya saat di pasar sebelumnya. Hal tersebut menjadikan suatu kendala bagi pedagang dalam beradaptasi dengan lokasi dan pelanggan baru sehingga akan mempengaruhi tingkat penjualan serta dapat mempengaruhi tingkat pendapatan pedagang. Selama relokasi Pasar Johar yang berada di kawasan Masjid Agung Jawa Tengah (MAJT) tersebut, kondisi pasar memang menjadi baik dan bersih, hal itu tentu menguntungkan pedagang dan pasti akan mempengaruhi pendapatan pedagang di pasar tersebut. Namun, meskipun demikian masih terdapat banyak pedagang yang mengaku mengeluhkan penurunan pendapatan mencapai $50 \%$ sampai $70 \%$ dibandingkan dengan Pasar Johar sebelumnya. Untuk itu menjadi penting mengkaji bagaimana proses rekolasi yang tidak merugikan pedagang dan apa yang menjadi penyebab utama kerugian tersebut.

Dalam kegiatan berdagang terdapat beberapa faktor yang mempengaruhi pendapatan, menurut Swasta dan Irawan (2008:201), faktor-faktor tersebut antara lain: kondisi dan kemampuan pedagang, kondisi pasar, modal, kondisi organisasi usaha dan faktor lain. Salah satu hal paling penting yang dibutuhkan dalam usaha yaitu modal. Pedagang di Pasar Johar Semarang merasa keterbatasan modal, pedagang yang terkena musibah mengalami kerugian besar dalam segi financial dengan adanya relokasi menuntut pedagang untuk berpindah ke lokasi berdagang yang baru yang membutuhkan modal lagi dalam jumlah yang lebih besar, dengan adanya modal yang besar tersebut sebagai biaya membangun kembali usahanya di lokasi yang baru. Pedagang mengalami masalah keterbatasan permodalan yaitu kurang adanya fasilitas peminjaman modal yang disediakan pihak pengelola pasar, adanya kesulitan melakukan peminjaman modal lewat lembaga keuangan bank maupun non-bank karena kurang adanya kepercayaan penuh dari lembaga peminjaman tersebut. Selain itu juga karena tingginya agunan yang ditetapkan sebagai jaminan atas pinjaman.

Berkaitan dengan pentingnya modal tersebut, menurut Hidayat (2010:77) bahwa modal adalah uang yang tidak dibelanjakan, jadi disimpan kemudian diinvestasikan. Maka dari itu, dengan meningkatkan jumlah modal yang digunakan maka juga akan meningkatkan pendapatan karena semakin tinggi modal yang digunakan maka akan juga menentukan pendapatan yang diperoleh sebab usaha yang akan dirintis akan luas dengan adanya modal yang besar. Sehingga dapat disimpulkan bahwa semakin besar modal maka akan dapat menambah atau meningkatkan jumlah produktivitas sehingga dapat meningkatkan penjualan dan juga dapat meningkatkan pendapatan. Hal tersebut sesuai dengan penelitian yang dilakukan oleh Atun (2016), Pratama (2013) dan Utami \& Edi (2013) yang menyatakan bahwa modal berpengaruh positif dan signifikan terhadap pendapatan. Dalam penelitian tersebut juga menyatakan bahwa salah satu cara untuk meningkatkan pendapatan adalah dengan meningkatkan modal.

Faktor lama usaha juga merupakan hal penting yang dapat mempengaruhi pendapatan, semakin lama seseorang melakukan usahanya maka akan memiliki strategi yang lebih matang dan tepat dalam mengelola, memproduksi dan memasarkan produknya, karena pengusaha atau pedagang tersebut memiliki pengalaman, pengetahuan serta mampu mengambil keputusan dalam kondisi dan keadaan apapun. Selain itu seseorang yang lebih lama melakukan usahanya akan semakin memiliki relasi atau pelanggan yang lebih banyak. Rata-rata pedagang di Pasar Johar telah berdagang selama puluhan tahun di lokasi yang sebelumnya, sedangkan masalahnya yaitu semenjak terjadinya kebakaran, pedagang dipindah ke Pasar Johar sementara yang hampir dua tahun ini, jumlah pedagang menjadi turun dibandingkan saat masih berada di Pasar Johar sebelumnya, banyak pedagang yang kurang optimis untuk melanjutkan usaha berdagangnya di lokasi pasar yang baru dan banyak pedagang yang gulung tikar atau memilih untuk tidak melanjutkan usahanya karena pedagang merasa takut semakin mengalami penurunan pendapatan secara terus menerus. Pedagang harus mampu be- 
radaptasi dengan pelanggan baru yang berada di sekitar pasar baru, pedagang mengaku telah kehilangan pelanggan lamanya di tempat mereka berdagang selama puluhan tahun tersebut.

Sesuai dengan yang dikemukakan oleh Simanjuntak (2001:74) bahwa seorang pengusaha dikatakan produktif bila ia mampu menghasilkan keluaran (output) lebih banyak, dalam hal ini pengalaman kerja akan memudahkan pekerjaan dalam memperoleh hasil yang lebih besar. Selain itu, Sudarman (1990:66) menyatakan bahwa besarnya pendapatan seseorang tergantung pada sedikit banyaknya waktu yang digunakan untuk bekerja, semakin lama ia bekerja akan semakin besar pula pendapatannya. Sehingga dapat disimpulkan bahwa semakin lama seseorang dalam melakukan usahanya, maka semakin tinggi pula pendapatannya. Hal tersebut sesuai penelitian Utami \& Edi (2013) dan Damariyah (2015) menyatakan bahwa lama usaha berpengaruh positif dan signifikan terhadap pendapatan.

Dilihat dari faktor lokasi usaha, pedagang mengaku bahwa lokasi relokasi Pasar Johar juga sangat mempengaruhi tingkat pendapatan pedagang karena lokasi pasar yang dahulu berada di pusat kota semarang yang berada di Jalan KH. Agus Salim, Kauman, Semarang Tengah, Kota Semarang. Lokasi tersebut berada di jalur lalu lintas utama, berada dekat dengan stasiun kereta api dan dekat dengan lokasi wisata Kota Semarang sehingga merupakan lokasi yang sangat strategis dan berada dipusat keramaian.

Sedangkan lokasi relokasi Pasar Johar yang saat ini berada di kawasan Masjid Agung Jawa Tengah (MAJT) yaitu di Jalan Arteri Soekarno-Hatta, Kelurahan Sambirejo Kecamatan Gayamsari Semarang yang dirasa jauh dari keramaian. Selain itu, jarak tempuh yang jauh dari Pasar Johar yang sebelumnya menjadi salah satu kendala bagi pedagang sehingga banyak pedagang yang lebih memilih untuk tidak melanjutkan usahanya karena jarak tempuh yang cukup jauh, para pedagang yang masih melanjutkan usahanya pun rata-rata juga harus menambah biaya transportasi untuk sampai di lokasi berdagang, baik itu kendaraan pribadi maupun angkutan umum. Hal ini karena sebagian besar pedagang berasal dari daerah sekitar pasar johar sebelumnya, dimana dahulunya mereka hanya perlu berjalan kaki atau menggunakan kendaraan pribadi dengan jarak tempuh yang lebih dekat untuk menuju lokasi berdagang, sedangkan saat ini mereka harus menggunakan jasa angkutan umum atau kendaraan pribadi dengan jarak tempuh yang lebih jauh untuk menuju tempat berdagang di lokasi relokasi tersebut. Sehingga hal itu menyebabkan bertambahnya biaya transportasi yang muncul akibat perpindahan lokasi pasar tersebut.

Dengan adanya perubahan tersebut menyebabkan kenaikan pada biaya operasional sedangkan pendapatan yang mereka peroleh mengalami penurunan. Kendala tersebut tidak hanya dialami oleh pedagang saja, namun juga dikeluhkan oleh pelanggan lama yang tidak mengerti atau bingung dengan lokasi yang baru. Pelanggan merasa enggan untuk berbelanja di lokasi relokasi Pasar Johar karena akses menuju pasar yang mengalami kesulitan mencari transportasi.

Penelitian terdahulu yang dilakukan oleh Pratama (2013), Damariyah (2015) dan Atun (2016) menegaskan bahwa lokasi usaha berpengaruh positif dan signifikan terhadap pendapatan.

Sampai saat ini masih terdapat pedagang yang menempati posisi berdagangnya tidak sesuai dengan zoning atau penataan yang menjadi satu blok dengan jenis dagangannya yang sesuai dengan aturan pengelola Pasar Johar Semarang. Pedagang mengaku bahwa alasan tersebut karena pedagang yang menempati kios atau los di bagian dalam atau belakang merasa tempatnya kurang strategis yaitu letaknya jauh dari keramaian dan berada di bagian pojok pasar. Pengelola pasar Johar Semarang sudah berupaya melakukan menertibkan pedagang berkali-kali namun pedagang masih tetap tidak menghiraukan penataan dari pengelola pasar. Hal itu juga merupakan faktor yang mempengaruhi sepinya pelanggan dimana pelanggannya menjadi kebingungan mencari pedagang langganannya 
sehingga dapat mengurangi tingkat penjualan dan otomatis dapat mengurangi tingkat pendapatan pedagang.

Pendapatan atau keuntungan ekonomi adalah pendapatan total yang diperoleh pengusaha setelah dikurangi oleh biaya produksi (Sukirno, 2006:37). Pendapatan merupakan hasil yang didapatkan melalui kegiatan suatu usaha yaitu kegiatan jual beli dengan melakukan transaksi antara penjual dan pembeli dengan adanya kesepakatan bersama. Pendapatan yang diterima adalah dalam bentuk uang, dimana uang merupakan alat pembayaran dan alat penukaran (Samuelson \& Nordhaus, 2003). Swasta dan Irawan (2008:201) mengatakan bahwa faktor-faktor yang mempengaruhi pendapatan dari kegiatan penjualan antara lain: (1) kondisi dan kemampuan pedagang; (2) transaksi jual beli yaitu mampu menyakinkan para pembeli untuk membeli dagangannya dan sekalipun memperoleh pendapatan yang diinginkan; (3) kondisi pasar; (4) modal; (5) kondisi organisasi penjualan; (6) faktor lain seperti periklanan, peragaan, kampanye, pemberian hadiah sering mempengaruhi penjualan.

Menurut Boediono (2002:89) secara garis besar pendapatan digolongkan menjadi tiga, yaitu (1) gaji dan upah; (2) pendapatan dari usaha sendiri; (3) pendapatan dari usaha lain. Sedangkan Gilarso (1992:62), menyebutkan pendapatan keluarga dapat diperoleh melalui berbagai sumber di antaranya (1) usaha sendiri (wiraswasta) contohnya berdagang, mengerjakan garapan lahan, dan menjalankan perusahaannya sendiri; (2) bekerja pada orang lain, contohnya bekerja dikantor atau perusahaan sebagai karyawan baik swasta maupun di golongan pemerintah; (3)hasil dari milik sendiri, contohnya memiliki sawah, rumah yang dikontrakkan atau dibuat kost, memiliki uang yang dipinjamkan dengan bunga, gaji pensiunan bagi mereka yang sudah lanjut usia, dan dahulunya bekerja baik pada pemerintah atau instansi lainnya; (4) sumbangan atau hadiah, contohnya mendapatkan sumbangan atau bantuan dari keluarga, warisan orang tua, hadiah, tabungan dan lain-lain; (5) pinjaman atau hutang yaitu merupakan uang masuk tetapi pada suatu saat harus dikembalikan atau dilunasi. Temuan Mubyarto (2009:107) sampai pada kesimpulan bahwa modal menghasilkan barang baru atau merupakan alat untuk memupuk pendapatan maka ada minat atau dorongan untuk menciptakan modal (capital formation). Menguatkan temuan Mubyarto, Hidayat (2010:77) menyatakan bahwa modal merupakan uang yang tidak dibelanjakan, jadi disimpan kemudian diinvestasikan. Hidayat juga menyimpulkan bahwa dengan meningkatkan jumlah modal yang digunakan maka juga akan meningkatkan pendapatan. Dengan kata lain, semakin tinggi modal yang digunakan maka akan juga menentukan pendapatan yang diperoleh; sebab usaha yang akan dirintis akan luas dengan adanya modal yang besar.

Menurut Sukirno (2006:122), modal terdapat dua macam yaitu modal tetap dan modal tidak tetap. Modal dalam suatu usaha harus mampu memenuhi dalam membiayai pengeluaran atau operasional usaha seharihari karena dengan adanya dukungan modal yang besar dan memadai maka akan dapat memudahkan dalam memenuhi kebutuhan operasional usaha sehingga suatu usaha tersebut tidak kesulitan dalam keuangan selain itu juga memberikan dampak besar bagi keberlangsungan suatu usaha yaitu meminimalisasi terjadinya kebangkrutan usaha.

Kebutuhan modal kerja dapat dipenuhi dari diri sendiri maupun dari pihak lain berupa pinjaman atau kredit. Menurut Prawirosoentono (2007:118) berdasarkan sumber-sumber modal dapat dibedakan menjadi dua, yaitu (1) modal sendiri yaitu modal yang berasal dari investasi sendiri dalam bentuk (a) saham (stock); (b) cadangan penyusutan (depreciation allowance) (c) Laba yang ditahan (retained earning), dan (2) modal pinjaman yaitu modal yang berasal dari pihak lain, baik dari lembaga institusional maupun lembaga non institusional. Secara umum sumber modal yang dapat diperoleh suatu usaha untuk memenuhi kebutuhan modalnya terdiri dari modal sendiri dan modal pinjaman.

Adapun lama usaha adalah jangka waktu pengusaha dalam menjalankan usa- 
hanya atau masa kerja seseorang dalam menekuni suatu bidang pekerjaan. Sudarman (1990:66) menyatakan bahwa besarnya pendapatan seseorang tergantung pada sedikit banyaknya waktu yang digunakan untuk bekerja, semakin lama ia bekerja akan semakin besar pula pendapatannya. Menurut Moenir (1988: 41) dan Suroto (2002:237) tentang lama usaha bahwa semakin lama seseorang dalam bekerja, maka semakin berpengalaman, matang dan mahir dalam pekerjaannya.

Menurut Foster (2001:43), ada beberapa hal untuk menentukan berpengalaman seseorang yang sekaligus sebagai indikator lama usaha yaitu (1) masa kerja merupakan ukuran tentang masa kerja yang telah ditempuh seseorang dapat memahami tugastugas suatu pekerjaan dan telah melaksakan dengan baik. (2) tingkat pengetahuan dan keterampilan merupakan pengetahuan yang merujuk pada konsep, prinsip, prosedur, kebijakan atau informasi lain yang dibutuhkan oleh seseorang; (3) penguasaan terhadap pekerjaan dan peralatan merupakan tingkat penguasaan seseorang dalam pelaksanaan aspek-aspek teknik peralatan dan teknik pekerjaan. Sedangkan menurut Pangestu (2005:13) termasuk dalam pengalaman berdagang adalah peningkatan pengetahuan dasar bagi para pedagang yang meliputi (1) pelatihan administrasi pembukuan; (2) pelatihan strategi penjualan; (3) sistem stok dan pengiriman barang; (4) informasi harga barang di pasar.

Selanjutnya, Tarigan (2005:122) menyimpulkan bahwa untuk menentukan lokasi usaha perlu adanya pertimbangan yang matang karena lokasi usaha merupakan salah satu strategi dalam usaha yang dapat menentukan tingkat pendapatan suatu usaha. Faktor-faktor pemilihan tempat atau lokasi usaha menurut Fandy (2002:92) di antaranya (1) aksesibilitas; (2) visibilitas; (3) lalu lintas (traffic); (4) ekspansi; (5) lingkungan; (6) persaingan.

Tarigan (2005:145) juga menyimpulkan bahwa dalam teori lokasi pendekatan losch mengatakan bahwa lokasi penjual sangat berpengaruh terhadap jumlah konsumen yang digarapnya. Semakin jauh dari tempat penjual, konsumen makin enggan membeli karena biaya transportasi untuk mendatangi tempat penjual semakin mahal. Produsen harus memilih lokasi yang menghasilkan penjualan terbesar yang identik dengan penerimaan terbesar. Dalam hal ini lokasi usaha sebagai salah satu faktor yang dapat mempengaruhi pendapatan karena lokasi usaha yang strategis dapat mempengaruhi tingkat pendapatan usaha.

Menguatkan Tarigan, Buchari (2012:106) sampai pada kesimpulan bahwa salah satu hal yang sangat menentukan tingkat keberhasilan dan kegagalan bisnis untuk masa depan yaitu memilih lokasi bisnis yang tepat dan strategis. Dalam memilih dan menetapkan lokasi bisnis terdapat dua langkah yang perlu ditetapkan yaitu menentukan masyarakat yang akan dilayani dan memilih lokasi disekitar masyarakat tersebut, dalam menentukan lokasi di dalam masyarakat tertentu.

Penelitian ini mengkaji variabel lama usaha yang tidak banyak digunakan pada penelitian sebelumnya seperti Atun (2016) dengan judul "Pengaruh Modal, Lokasi dan Jenis Dagangan terhadap Pendapatan Pedagang Pasar Prambanan Kabupaten Sleman". Perbedaan lain juga terletak pada penggunaan teori pada variabel lokasi usaha, di mana penelitian terdahulu pada variabel lokasi usaha menggunakan indikator dari Alma (2012). Sedangkan pada penelitian ini variabel lokasi usaha menggunakan indikator dari Fandy (2002) yang meliputi aksesibilitas, visibilitas, lalu lintas, lokasi parkir, ekspansi, lingkungan dan persaingan. Hal tersebut lebih tepat digunakan dalam menggali permasalahan pendapatan pedagang khusunya pada pedagang pasar relokasi.

Relokasi Pasar Johar Semarang merupakan peristiwa terkini yang dikaji dalam penelitian ini. Berdasarkan permasalahan tersebut penelitian ini bertujuan: (1) mengetahui pengaruh modal, lama usaha dan lokasi usaha terhadap pendapatan pedagang pasca relokasi Pasar Johar di Kota Semarang secara bersama-sama; (2) mengetahui pengaruh modal terhadap pendapatan peda- 
gang pasca relokasi Pasar Johar di Kota Semarang; (3) mengetahui pengaruh antara lama usaha terhadap pendapatan pedagang pasca relokasi Pasar Johar di Kota Semarang, dan (4) mengetahui pengaruh lokasi usaha terhadap pendapatan pedagang pasca relokasi Pasar Johar di Kota Semarang.

\section{METODE}

Penelitian ini dilakukan dengan menggunakan metode penelitian kuantitatif, yaitu meneliti pengaruh variabel bebas yaitu modal, lama usaha dan lokasi usaha dengan variabel terikat yaitu pendapatan (Sugiyono,2015:14). Sedangkan jenis penelitian ini menggunakan rumusan masalah asosiatif dan bentuk hubungan kausalitas. Populasi peneliti ini seluruh pedagang Pasar Johar Semarang yang berada di lokasi relokasi yaitu di Jalan Arteri Soekarno-Hatta di Kelurahan Sambirejo Kecamatan Gayamsari Semarang yang berjumlah 1.206 pedagang dari semua jenis barang dagangan di Pasar Johar Semarang. Sampel sebanyak 92 pedagang dengan teknik proportional random sampling. Berdasarkan teknik tersebut, didapatkan proporsi sampel (tabel 3).

Metode pengumpulan data menggunakan wawancara, angket atau kuesioner dan dokumentasi. Analisis data dalam penelitian ini menggunakan analisis deskriptif persentase dan analisis regresi linier berganda. Analisis ini digunakan untuk mengetahui ada tidaknya pengaruh antara modal, lama usaha dan lokasi usaha terhadap pendapatan, baik pengaruhnya secara individual (parsial) atau bersama-sama (simultan). Rumus regresi dengan tiga variabel menurut Purwanto (2013:210) sebagai berikut: $\mathrm{Y}=\mathrm{a}+b_{1} X_{1}+b_{2} X_{2}+b_{3} X_{3}$

\section{HASIL DAN PEMBAHASAN}

Pasar Johar merupakan salah satu pasar tradisional di Kota Semarang. Menurut Dinas UPTD Pasar Johar Semarang, Pasar Johar merupakan pasar terbesar yang menjadi pusat jual beli di Kota Semarang yang terkenal dengan komoditinya dan menjadi salah satu pusat destinasi belanja masyarakat. Pasar Johar yang merupakan warisan budaya peninggalan Belanda ini terletak di kawasan perdagangan di pusat dan berdekatan dengan dengan kawasan kota lama yang berkembang menjadi wisata sejarah di Kota Semarang. Pasar Johar pernah mendapat penghargaan sebagai pasar terbesar dan termodern di Asia Tenggara pada tahun 1930. Pasar Johar memiliki luas 15.003,50 meter persegi, didirikan pada tahun 1939 oleh Arsitek Belanda Ir. Thomas Karsten. Pasar yang bersatu yaitu Pasar Johar, Pasar Pedamaran, Pasar Benteng, Pasar Jurnatan, dan Pasar Pekojan. Pada perkembangan ide pembangunan bentuk Pasar Johar memunculkan berbagai konstruksi cendawan, dari sinilah Pasar Johar semakin tersohor.

Namun, sejak mengalami musibah kebakaran pada tanggal 9 mei 2015, bangunan Pasar Johar mengalami kerusakan di beberapa bagian. Sehingga tepat pada tanggal

Tabel 3. Data Jumlah Populasi dan Sampel

\begin{tabular}{llccc}
\hline No & \multicolumn{1}{c}{ Jenis Dagangan } & $\begin{array}{c}\text { Jumlah } \\
\text { Populasi }\end{array}$ & Perhitungan & $\begin{array}{c}\text { Jumlah } \\
\text { Sampel }\end{array}$ \\
\hline 1 & Sembako & 132 & $132 \times 92 / 1206$ & 10 \\
2 & Sayuran & 178 & $178 \times 92 / 1206$ & 13 \\
3 & Daging dan ikan & 60 & $60 \times 92 / 1206$ & 5 \\
4 & Buah-buahan & 137 & $137 \times 92 / 1206$ & 10 \\
5 & Makanan dan minuman & 105 & $105 \times 92 / 1206$ & 8 \\
6 & Pakaian & 336 & $336 \times 92 / 1206$ & 26 \\
7 & Sepatu & 41 & $41 \times 92 / 1206$ & 3 \\
8 & Tas & 25 & $25 \times 92 / 1206$ & 2 \\
9 & Buku & 19 & $19 \times 92 / 1206$ & 1 \\
10 & Aksesoris dan souvenir & 86 & $86 \times 92 / 1206$ & 7 \\
11 & Elektronik & 13 & $13 \times 92 / 1206$ & 1 \\
12 & Peralatan rumah tangga & 74 & $74 \times 92 / 1206$ & 6 \\
\end{tabular}

Sumber : Data primer yang diolah, 2017. 
19 januari 2016, Pemerintah Daerah Kota Semarang memutuskan untuk melakukan kegiatan relokasi atau pemindahan lokasi berdagang Pasar Johar yang semula ke lokasi Pasar Johar sementara di kawasan Masjid Agung Jawa Tengah (MAJT) yaitu berada di Jalan Arteri Soekarno-Hatta di Kelurahan Sambirejo Kecamatan Gayamsari Semarang.

Bangunan Pasar Johar sementara yang saat ini berada di kawasan Masjid Agung Jawa Tengah (MAJT) terdiri dari kios sebanyak 1.143, los/dasaran terbuka sebanyak 63, mushola sebanyak 1, toilet/ MCK sebanyak 7, kantor dinas UPTD sebanyak 1, kantor kepala pasar sebanyak 2 dan pos keamanan sebanyak 2. Lokasi tersebut berjarak 5,3 kilometer dari lokasi Pasar Johar sebelumnya. Terkait jumlah pedagang sebelum dilakukan relokasi, jumlah semula sebanyak 6.087 orang. Namun setelah dilakukan relokasi jumlahnya menjadi berkurang yaitu sebanyak 1.206 pedagang.

H1: terdapat pengaruh modal, lama usaha dan lokasi usaha terhadap pendapatan pedagang pasca relokasi Pasar Johar di Kota Semarang

Berdasarkan hasil pengujian hipotesis penelitian menggunakan alat uji statistik yaitu uji simultan (Uji F) menunjukkan adanya pengaruh modal, lama usaha dan lokasi usaha terhadap pendapatan. Hasil uji simultan nilai $\mathrm{F}$ hitung sebesar 74,922 lebih besar dari $\mathrm{F}$ tabel 2,71 dengan signifikansi 0,000 lebih kecil dari 0,05 sehingga menunjukkan bahwa terdapat pengaruh positif antara modal, lama usaha dan lokasi usaha terhadap pendapatan pedagang di Pasar Johar Semarang. Hal ini mengandung makna bahwa semakin tinggi modal dan lama usaha serta semakin baik lokasi usaha maka semakin tinggi pula pendapatan pedagang.

Hasil uji koefisien determinasi simul$\tan \left(\mathrm{R}^{2}\right)$ diketahui besarnya Adjust $R$ Square menunjukkan bahwa 70,9\% variabel pendapatan dapat dijelaskan oleh variabel modal, lama usaha dan lokasi usaha sedangkan sisanya sebesar $29,1 \%$ dijelaskan oleh variabel lain diluar penelitian. Secara simultan ketiga variabel bebas berpengaruh terhadap variabel terikat, maka ketiga variabel bebas terse- but dapat dijadikan perhatian bagi pihak pasar dan pemerintah daerah dalam hal meningkatkan pendapatan pedagang.

Selain itu berdasarkan hasil uji koefisien determinasi parsial $\left(\mathrm{r}^{2}\right)$ besarnya variabel modal sebesar 27,9\%, lama usaha sebesar 13,0\% dan lokasi usaha sebesar $19,8 \%$. Dari ketiga variabel tersebut, variabel modal memberikan pengaruh paling besar terhadap pendapatan, dan variabel lama usaha merupakan variabel yang memberikan pengaruh paling kecil terhadap pendapatan.

Hasil analisis deskriptif variabel pendapatan menunjukkan bahwa secara keseluruhan rata-rata para pedagang memiliki pendapatan rendah yaitu dalam satu bulan sebesar 5.000.000-10.000.000. Pedagang perlu menjaga dan meningkatkan pendapatannya, agar tidak mengalami kerugian secara terus menerus dan mampu mencukupi kebutuhan usahanya. Persentase variabel pendapatan dengan rata-rata sebesar 51\% dengan kategori rendah. Variabel modal dengan rata -rata sebesar 53\% dengan kategori sangat rendah, sedangkan lama usaha dalam kategori rendah dengan rata-rata sebesar 46\% serta lokasi usaha dikatakan kurang baik dengan rata-rata sebesar $60 \%$.

Hasil penelitian ini menunjukkan bahwa secara keseluruhan rata-rata pendidikan terakhir pedagang di Pasar Johar Semarang yaitu tngkat Sekolah Dasar (SD) sebanyak 35 pedagang sedangkan pada blok dagangan pada penelitian ini terbanyak pada blok $G$ sebanyak 20 pedagang. Hasil penelitian ini mendukung penelitian Artaman (2015) bahwa pendapatan dipengaruhi oleh beberapa faktor di antaranya modal, lama usaha, jam kerja, parkir dan lokasi usaha.

H2: terdapat pengaruh positif dan signifikan modal terhadap pendapatan pedagang pasca relokasi Pasar Johar di Kota Semarang.

Hasil uji hipotesis secara parsial (uji t) menunjukkan bahwa variabel modal memiliki nilai signifikansi sebesar 0,000 yang mana nilai tersebut lebih kecil dari taraf signifikansi yang diinginkan yaitu 0,05 . Oleh karena itu hasil signifikansi lebih kecil dari 0,05 
maka hipotesis pertama diterima dengan hasil yang signifikan. Hasil tersebut menyatakan bahwa terdapat pengaruh positif antara modal terhadap pendapatan. Dalam koefisien determinasi persial $\left(\mathrm{r}^{2}\right)$ menunjukkan bahwa besarnya pengaruh modal terhadap pendapatan sebesar $27,9 \%$.

Hasil penelitian ini sesuai dengan pendapat Hidayat (2010:77) yaitu dengan meningkatkan jumlah modal yang digunakan maka juga akan meningkatkan pendapatan karena semakin tinggi modal yang digunakan maka akan menentukan pendapatan yang diperoleh sebab usaha yang akan dirintis akan luas dengan adanya modal yang besar. Hal tersebut sesuai dengan penelitian terdahulu yang dilakukan oleh Atun (2016), Pratama (2013) dan Utami \& Edi (2013) yang menyatakan bahwa modal berpengaruh positif dan signifikan terhadap pendapatan. Dalam penelitian tersebut juga menyatakan bahwa salah satu cara untuk meningkatkan pendapatan adalah dengan meningkatkan modal.

Dalam penelitian ini indikator yang digunakan untuk mengukur modal yaitu jumlah modal dan sumber modal. Menurut Prawirosoentono (2007:118) secara umum sumber modal yang dapat diperoleh suatu usaha untuk memenuhi kebutuhan modalnya terdiri dari modal sendiri dan modal pinjaman. Sedangkan menurut Sukirno (2006:122), macam modal terdiri dari modal tetap dan modal tidak tetap. Indikator yang digunakan dalam penelitian ini untuk mengukur variabel modal adalah jumlah modal yang terdiri dari modal tetap atau yang disebut modal awal, serta modal tidak tetap yang disebut modal operasional yang digunakan untuk kebutuhan usaha sehari-hari maupun tiap bulan atau dapat disebut juga modal ku- lakan, dan sumber modal yang terdiri dari modal sendiri dan modal pinjaman dari lembaga keuangan bank maupun non-bank. Pengaruh modal terhadap pendapatan artinya bahwa dengan modal awal maupun modal operasional yang tinggi serta adanya kemudahan peminjaman modal maka suatu usaha akan lebih mudah dalam memenuhi kebutuhan usahanya serta dapat meningkatkan pendapatan pedagang di Pasar Johar Semarang. Dalam penelitian ini diperoleh hasil analisis deskriptif persentase variabel modal yang diperoleh dari 92 responden. Hasil deskriptif persentase variabel modal dapat dilihat pada tabel 4 .

Secara keseluruhan variabel modal diperoleh nilai rata-rata sebesar 53\% dengan kriteria sangat rendah (table 4). Hal ini menunjukkan bahwa jumlah modal pedagang dalam kategori sangat rendah dengan nilai rata-rata sebesar $48 \%$ dimana modal awal sebesar kurang dari Rp 2.000.000 sampai $\mathrm{Rp} 10.000 .000$ dan modal operasional sebesar kurang dari Rp 1.000.000 sampai Rp 5.000.000. Selain itu sumber modal pedagang dalam kategori sangat rendah yaitu dengan nilai rata-rata sebesar 59\%, mayoritas pedagang menggunakan sumber modal sendiri untuk melakukan usahanya sedangkan untuk penambahan modal pinjaman terdapat kendala kurangnya fasilitas lembaga pinjaman bagi pedagang serta pedagang merasa terbentur dari kemampuan pedagang yang tidak dapat memenuhi syarat yaitu adanya jaminan atau agunan yang harus diberikan untuk mendapatkan pinjaman baik dari lembaga keuangan bank maupun non bank. Sehingga dapat disimpulkan bahwa semakin tinggi modal maka pendapatan juga akan tinggi. Adanya modal yang tinggi tersebut

Tabel 4. Analisis Deskriptif Modal

\begin{tabular}{cccc}
\hline Interval & Kriteria & Frekuensi & Persentase \\
\hline $21-25$ & Sangat tinggi & 1 & $1 \%$ \\
$16-20$ & Tinggi & 9 & $10 \%$ \\
$11-15$ & Rendah & 32 & $36 \%$ \\
$6-10$ & Sangat rendah & 50 & $53 \%$ \\
\hline & Jumlah & 92 & $100 \%$ \\
& Rata-rata & & $53 \%$ \\
& Kriteria & & Sangat rendah \\
\hline
\end{tabular}


akan dapat memenuhi kebutuhan usaha serta dapat menambah jumlah dan variasi barang dagangan sehingga akan lebih mudah menarik minat pelanggan dalam berbelanja dan hal tersebut otomatis akan menambah pendapatan pedagang di Pasar Johar Semarang.

H3: terdapat pengaruh positif dan signifikan lama usaha terhadap pendapatan pedagang pasca relokasi Pasar Johar di Kota Semarang.

Hasil uji hipotesis secara parsial (uji t) menunjukkan bahwa variabel lama usaha memiliki nilai signifikansi sebesar 0,000 yang mana nilai tersebut lebih kecil dari taraf signifikansi yang diinginkan yaitu 0,05. Oleh karena itu hasil signifikansi lebih kecil dari 0,05 maka hipotesis pertama diterima dengan hasil yang signifikan. Hasil tersebut menyatakan bahwa terdapat pengaruh positif antara lama usaha terhadap pendapatan. Dalam koefisien determinasi persial $\left(\mathrm{r}^{2}\right)$ menunjukkan bahwa besarnya pengaruh lama usaha terhadap pendapatan sebesar 13,0\%. Hasil penelitian ini menguatkan temuan Sudarman (1990:66), bahwa besarnya pendapatan seseorang tergantung pada sedikit banyaknya waktu yang digunakan untuk bekerja, semakin lama ia bekerja akan semakin besar pula pendapatannya. Berdasarkan hasil penelitian di atas dapat disimpulkan bahwa lama usaha yang tinggi akan menimbulkan pendapatan yang tinggi pula. Hal tersebut sesuai dengan penelitian terdahulu yang dilakukan oleh Utami \& Edi (2013) dan Damariyah (2015), bahwa lama usaha berpengaruh positif dan signifikan terhadap pendapatan.

Dalam penelitian ini variabel lama usaha menggunakan indikator menurut teori Foster (2001:43) yang menyatakan bahwa ada beberapa hal untuk menentukan berpengalaman seseorang di-antaranya masa kerja, tingkat pengetahuan dan keterampilan dan penguasaan terhadap pekerjaan dan peralatan. Apabila hal tersebut terpenuhi maka akan menjadikan seorang pedagang lebih berpengalaman dengan seiring waktu tersebut sehingga akan lebih memiliki strategi yang tepat untuk usahanya dan hal tersebut dapat meningkatkan penjualan dan otomatis akan menambah pendapatan. Dalam penelitian ini diperoleh hasil analisis deskriptif prsentase variabel lama usaha yang diperoleh dari 92 responden. Hasil deskriptif persentase variable lama usaha dapat dilihat pada tabel 5 .

Berdasarkan hasil analisis deskriptif persentase (tabel 5) diketahui bahwa secara keseluruhan variabel lama usaha diperoleh rata-rata sebesar 54\% dengan kriteria rendah. Hal ini menunjukkan bahwa lama usaha pedagang di Pasar Johar Semarang dalam kategori rendah artinya sebagian besar pedagang merasa bahwa tingkat lama usaha yang dijalankan di Pasar Johar Semarang masih rendah. Berdasarkan hasil persentase masa kerja diperoleh persentase nilai rata-rata sebesar $52 \%$, hal tersebut menunjukkan bahwa pedagang di Pasar Johar Semarang memiliki masa kerja kurang dari 10 tahun dan termasuk dalam kategori rendah, namun tingkat pengetahuan dan keterampilan pedagang dalam kategori tinggi dengan nilai rata-rata sebesar $47 \%$, sedangkan pada penguasaan terhadap pekerjaan dan peralatan dalam kategori tinggi dengan nilai rata-rata sebesar $47 \%$.

Tabel 5. Analisis Deskriptif Lama Usaha

\begin{tabular}{cccc}
\hline Interval & Kriteria & Frekuensi & Persentase \\
\hline $30-36$ & Sangat tinggi & 4 & $4 \%$ \\
$23-29$ & Tinggi & 33 & $37 \%$ \\
$16-22$ & Rendah & 42 & $46 \%$ \\
$9-15$ & Sangat Rendah & 12 & $13 \%$ \\
\hline & Jumlah & 92 & $100 \%$ \\
& Rata-rata & \multicolumn{2}{c}{ Rendah } \\
\hline
\end{tabular}


H4: terdapat pengaruh positif dan signifikan lokasi usaha terhadap pendapatan pasca relokasi Pasar Johar di Kota Semarang.

Hasil uji hipotesis secara parsial (uji t) menunjukkan bahwa variabel lokasi usaha memiliki nilai signifikansi sebesar 0,000 yang mana nilai tersebut lebih kecil dari taraf signifikansi yang diinginkan yaitu 0,05 . Oleh karena itu hasil signifikansi lebih kecil dari 0,05 maka hipotesis pertama diterima dengan hasil yang signifikan. Hasil tersebut menyatakan bahwa terdapat pengaruh positif antara lama usaha terhadap pendapatan. Dalam koefisien determinasi persial $\left(\mathrm{r}^{2}\right)$ menunjukkan bahwa besarnya pengaruh lama usaha terhadap pendapatan sebesar $19,8 \%$.

Hasil penelitian ini sejalan dengan teori lokasi pendekatan pasar Agust Losch (Tarigan, 2005:145) yaitu lokasi penjual sangat berpengaruh terhadap jumlah konsumen yang dapat digarapnya. Makin jauh dari tempat penjual, konsumen semakin enggan membeli karena biaya transportasi untuk mendatangi tempat penjual semakin mahal. Produsen harus memilih lokasi yang menghasilkan penjualan terbesar yang identik dengan penerimaan terbesar. Sehingga dapat ditarik kesimpulan bahwa lokasi berjualan berkaitan erat dengan keterikatan para pembeli untuk membeli barang dan akan berpengaruh terhadap pendapatan dari pedagang tersebut. Semakin baik atau strategis lokasi usaha maka pendapatan akan semakin tinggi. Hal tersebut sesuai dengan penelitian terdahulu yang dilakukan oleh Pratama (2013), Damariyah (2015) dan Atun (2016) menyatakan bahwa lokasi usaha berpengaruh positif dan signifikan terhadap pendapatan. Hasil analisis deskriptif persen- tase menunjukkan bahwa secara keseluruhan variabel lokasi usaha diperoleh ratarata 51\% dengan kriteria kurang baik. Dalam penelitian ini diperoleh hasil analisis deskriptif persentase variabel lokasi usaha yang di peroleh dari 92 responden. Hasil deskriptif persentase variabel lokasi usaha dapat dilihat pada tabel 6 .

Lokasi usaha di Pasar Johar Semarang dalam kategori kurang baik yang artinya sebagian besar pedagang merasa bahwa lokasi usaha di Pasar Johar Semarang tersedia dengan keadaan yang kurang baik (tabel 6). Pada deskriptif persentase indikator aksesibilitas berada dalam kategori baik dengan perolehan persentase nilai ratarata sebesar $47 \%$, hal tersebut menunjukkan bahwa akses menuju Pasar Johar Semarang dirasakan sudah baik. Indikator pada visibilitas atau kemudahan tempat usaha untuk dilihat atau ketahui berada dalam kategori kurang baik dengan nilai rata-rata sebesar $49 \%$, hal tersebut menunjukkan bahwa tempat usaha sulit untuk diketahui oleh pelanggan di mana dengan bentuk bangunan yang memanjang sehingga terdapat pedagang yang berjualan dibagian belakang atau pojok pasar.

Pada indikator lalu-lintas berada dalam kategori baik dengan nilai rata-rata sebesar 53\%, hal tersebut menunjukkan bahwa lalu lintas yang berada di sekitar pasar berjalan lancar dan tidak mengalami kemacetan sehingga akan memudahkan dalam melakukan aktivitas dipasar. Indikator lokasi parkir pada Pasar Johar Semarang berada dalam kategori baik dengan nilai ratarata sebesar $55 \%$ hal tersebut menunjukkan bahwa penyediaan fasilitas lokasi parkir dirasa sudah baik dimana berada di area pintu masuk pasar dan diamankan oleh

Tabel 6. Analisis Deskriptif Lokasi Usaha

\begin{tabular}{cccc}
\hline Interval & Kriteria & Frekuensi & Persentase \\
\hline $69-84$ & Sangat baik & 0 & $0 \%$ \\
$33-68$ & Baik & 28 & $30 \%$ \\
$37-52$ & Kurang baik & 55 & $60 \%$ \\
$21-36$ & Tidak baik & 9 & $10 \%$ \\
\hline & Jumlah & 92 & $100 \%$ \\
& Rata-rata & & $60 \%$ \\
& Kriteria & & Kurang baik \\
\hline
\end{tabular}


petugas parkir kendaraan. Indikator ekspansi atau ketersediaan luas usaha berada dalam kategori kurang baik dengan nilai ratarata $62 \%$. Hal tersebut menunjukkan bahwa pedagang merasa bahwa ketersediaan tempat usaha dirasa kurang luas sehingga tidak sesuai dengan kapasitas jumlah barang dagangan dan susah untuk mengembangkan usaha.

Pada indikator lingkungan berada pada kategori baik dengan nilai rata-rata 54\% hal tersebut menunjukkan bahwa sudah ada dukungan yang baik dari lingkungan masyarakat sekitar pasar. Sedangkan pada indikator persaingan berada dalam kategori baik dengan nilai rata-rata sebesar 57\%, hal ini menunjukkan bahwa dalam melakukan usaha berdagang di Pasar Johar Semarang para pedagang melalukan persaingan usaha dengan baik dan sehat.

Pengaruh lokasi usaha terhadap pendapatan artinya dengan lokasi usaha yang baik atau strategis maka akan mempermudah pedagang untuk menjual barang dagangannya dan memudahkan pelanggan untuk berbelanja. Hasil penelitian ini mendukung temuan Fandy (2002:92), bahwa lokasi usaha dikatakan strategis jika memenuhi kriteria-kriteria meliputi: aksesibilitas, visibilitas, lalu-lintas, lokasi parkir, ekspansi, lingkungan dan persaingan. Sehingga pertimbangan tersebut akan membawa pengaruh pada perolehan pendapatan pedagang. Begitu pula dengan pelanggan akan senang berbelanja dengan keadaan sebagaimana telah disebutkan.

\section{KESIMPULAN DAN SARAN Kesimpulan}

Berdasarkan hasil penelitian sebagaimana telah diuraikan, maka dapat disimpulkan: (1) Terdapat pengaruh positif dan signifikan modal, lama usaha dan lokasi usaha secara simultan terhadap pendapatan pedagang pasca relokasi Pasar Johar di Kota Semarang; (2) Terdapat pengaruh positif dan signifikan modal terhadap pendapatan pedagang pasca relokasi Pasar Johar di Kota Semarang; (3) Terdapat pengaruh positif dan signifikan lama usaha terhadap pendapatan pedagang pasca relokasi Pasar Johar di Kota
Semarang, dan (4) Terdapat pengaruh positif dan signifikan lokasi usaha terhadap pendapatan pedagang pasca relokasi Pasar Johar di Kota Semarang.

\section{Saran}

Berdasarkan hasil dan kesimpulan penelitian, maka dapat disampaikan saransaran sebagai berikut: (1) Modal perlu ditingkatkan karena besar kecilnya modal sangat mempengaruhi pendapatan. Peningkatan modal salah satunya dapat dilakukan dengan dikordinasikan melalui pengelola pasar dan lembaga keuangan agar pedagang dapat lebih mudah melakukan pinjaman modal; (2) Hendaknya pedagang selalu optimis dalam melakukan usaha berdagang, memiliki strategi pemasaran yang tepat agar dapat lebih mudah menarik minat pelanggan, dan (3) Pengelola Pasar Johar Kota Semarang lebih memperhatikan faktor-faktor pemilihan lokasi usaha seperti visibilitas dan ekspansi. Pasar sebaiknya berada tepat di dekat jalan raya dan penempatan usaha berdagang sesuai dengan jenis dagangan sehingga memudahkan pelanggan dalam berbelanja. Selain itu pengelola pasar menyediakan tempat usaha yang luas agar pedagang yang memiliki kapasitas tempat usaha sesuai dengan kapasitas barang dagangannya dan dapat mengembangkan usahanya.

\section{DAFTAR PUSTAKA}

Artaman, Dewa Made A., dkk.,. (2015). "Analisis Faktor-faktor yang Mempengaruhi Pendapatan Pedagang Pasar Seni Sukawati Gianyar". $E$ Jurnal Ekonomi dan Bisnis, Volume 4 No 2. Hal 93-102. Bali: Universitas Udayana Bali.

Atun, Nur Isni. (2016). "Pengaruh Modal, Lokasi, dan Jenis Dagangan terhadap Pendapatan Pedagang Pasar Prambanan Kabupaten Sleman". Jurnal Pendidikan dan Ekonomi, Volume 5, No. 4. Hal 324 Yogyakarta: Universitas Negeri Yogyakarta.

Buchari Alma. (2012). Pengantar Bisnis. Bandung: Alfabeta.

Boediono, (2002). Ekonomi Mikro. Yogyakar- 
ta: BPFE-UGM.

Badan Pusat Statistik Provinsi Jawa Tengah 2016 (di akses pada tanggal 08 April 2017).

Badan Pusat Statistik Kota Semarang 2016. (di akses pada tanggal 08 April 2017).

Damariyah. (2015). Pengaruh Modal Kerja, Lama Usaha, Jam Kerja, Lokasi Usaha Dan Tingkat Pendidikan Terhadap Pendapatan Pedagang (Studi Kasus di Pasar Desa Pandansari Kecamatan Warungasem. Skripsi. Hal 98-99 Pekalongan: Sekolah Tinggi Agama Islam Negeri (STAIN) Pekalongan.

Dinan, A., Kuncoro W., H., \& Iranto, D. (2017). "Analisis Perdagangan Internasional Terhadap Siklus Bisnis Di Asean-5 Periode 1999-2014". Jurnal Pendidikan Ekonomi \& Bisnis (Edisi Elektronik), 5(2), 126-129. Https:// Doi.Org/Https://Doi.Org/10.21009/ Jpeb.005.2.1

Dinas Unit Pelaksana Teknis Dasar (UPTD) Pasar Johar Semarang. 2017.

Fandy, Tjiptono. (2002). Pemasaran Jasa. Malang : Banyumedia Publishing.

Foster, Bill. (2001). Pembinaan Untuk Peningkatan Kinerja Karyawan. PPM: Jakarta.

Gilarso. (1992). Ekonomi Mikro "Suatu Pendekatan Praktis". Jakarta: Gramedia Pustaka Utama.

Hidayat, T. (2010). Buku Pintar Investasi. Jakarta: Media Kita.

Irawan dan Suparmoko. (1992). Ekonomi Pembangunan. Edisi kelima. Yogyakarta: BPFE-UGM.

Moenir, AS. (1988). Manajemen Pelayanan Umum Indonesia. Jakarta. Bumi Aksara.

Pangestu, Mari Elka. (2005). Buku Putih: Sambutan Menteri Perdagangan RI. Jakarta: Departemen Perdagangan Republik Indonesia.

Mubyarto. (2009). Peluang Kerja dan Berusaha di Pedesaan. Yogyakarta: BPFE UGM.

Peraturan Daerah Kota Semarang Nomor 9 Tahun 2013 tentang Pengaturan Pasar Tradisional.
Pratama, Aditya S. (2013). Analisis FaktorFaktor yang Mempengaruhi Pendapatan Pedagang Pasar Setelah Relokasi Di Pasar Purwoyoso Kecamatan Ngaliyan Semarang. Skripsi. Hal 45-49. Semarang. Universitas Negeri Semarang.

Prawirosoentono, Suyadi. (2007). Pengantar Bisnis Modern. Jakarta : PT. Bumi Aksara.

Purwanto, Suharyadi. (2013). Statistika untuk Ekonomi dan Keuangan Modern Edisi 2. Jakarta: Salemba Empat.

Simanjuntak. (2001). Pengantar Ekonomi Sumber Daya Manusia. Jakarta: Jilid II. LPFE.

Sudarman, Ari. (1990). Teori Ekonomi Mikro buku 1. Yogyakarta: BPFE-UGM.

Sugiyono. (2015). Metode Penelitian Bisnis. Cetakan enam belas. Bandung. CV Alfabeta.

Sukirno, Sadono. (2000). Ekonomi Pembangunan Proses, Masalah, dan Dasar Kebijakan Pembangunan. UI-Press. Jakarta.

(2006). Teori Pengantar Ekonomi Mikro. Jakarta: PT Raja Grafindo Persada.

Swasta, Basu dan Irawan. (2008). Manajemen Pemasaran Modern. Yogyakarta: Liberty.

Samuelson, Paul A \& William Nordhaus, (2003). Makroekonomi, Edisi 14. Jakarta: Erlangga.

Suroto. (2002). Strategi Pembangunan dan Perencanaan Kesempatan Kerja. Yogyakarta: Gajah Mada University Press.

Tarigan, Robinson. (2005). Ekonomi Regional Teori dan Aplikasi. Jakarta: PT. Bumi Aksara.

Utami, Setyaningsih Sri \& Edi Wibowo. (2013). "Pengaruh Modal Kerja Terhadap Pendapatan dengan ama Usaha sebagai Variabel Moderasi (Survei pada Pedagang Pasar Klithikan Notoharjo Surakarta)". Jurnal Ekonomi dan Kewirausahaan, Volume 13 No. 2. Hal 175-179. Surakarta: Universitas Slamet Riyadi Surakarta. 